Pesq. Vet. Bras. 35(1):75-79, janeiro 2015 DOI: $10.1590 / \mathrm{S} 0100-736 \mathrm{X} 2015000100015$

\title{
Transitional cell carcinoma of urinary bladder with metastasis in lumbar vertebrae and spinal cord compression in an ocelot (Leopardus pardalis) ${ }^{1}$
}

\author{
Karen Y.R. Nakagaki², Pâmela A. Lima², Kiyoko U. Utiumi², Marco A.M. Pires ${ }^{3}$, Rosana \\ Zanatta $^{3}$, Fabiana M. Boabaid ${ }^{4}$, Edson M. Colodel $^{5}$ and Djeison L. Raymundo ${ }^{2 *}$
}

\begin{abstract}
Nakagaki K.Y.R., Lima P.A., Utiumi K.U., Pires M.A.M., Zanatta R., Boabaid F.M., Colodel E.M. \& Raymundo D.L. 2015. Transitional cell carcinoma of urinary bladder with metastasis in lumbar vertebrae and spinal cord compression in an ocelot (Leopardus pardalis. Pesquisa Veterinária Brasileira 35(1):75-79. Setor de Patologia Veterinária, Departamento de Medicina Veterinária, Universidade Federal de Lavras, Cx. Postal 3037, Lavras, MG 37200-000, Brazil. E-mail: djeison.raymundo@dmv.ufla.br

This paper reports a case of nonpapillary and infiltrative transitional cell carcinoma (TCC) of the urinary bladder with metastasis of lumbar vertebrae and spinal cord compression in an adult female ocelot (Leopardus pardalis), from the Mato Grosso state, Brazil. The ocelot had pelvic limb paralysis and skin ulcers in the posterior region of the body and was submitted to euthanasia procedure. At necropsy was observed a multilobulated and irregular shaped, yellowish to white nodule in the urinary bladder. The nodule had a soft consistency and arised from the mucosa of the urinary bladder extending throughout the muscular layers and the serosa. Nodules of similar appearance infiltrating the vertebral column the at L6 and L7 vertebrae with corresponding spinal canal invasion were also observed. The histological evaluation showed epithelial neoplastic proliferation in the urinary bladder with characteristics of nonpapillary and infiltrative TCC, with positive immunohistochemical staining for pancytokeratin, and strong immunostaining for cytokeratin of low molecular weight, and weak or absent labeling for high molecular weight cytokeratin. This is the first report of TCC of urinary bladder in ocelot in Brazil.
\end{abstract}

INDEX TERMS: Transitional cell carcinoma, urinary bladder, ocelot, Leopardus pardalis, epithelial neoplasia, urinary system, immunohistochemistry, cytokeratin, wild feline.

RESUMO.- [Carcinoma de células de transição de bexiga urinária com metástase em vértebras lombares e compressão de medula espinhal em uma jaguatirica (Leopardus pardalis).] 0 presente trabalho relata um caso de carcinoma de células de transição (TCC) da bexiga

\footnotetext{
${ }^{1}$ Received on June 28, 2014.

Accepted for publication on December 19, 2014.

${ }^{2}$ Setor de Patologia Veterinária, Departamento de Medicina Veterinária, Universidade Federal de Lavras (UFLA), Cx. Postal 3037, Lavras, MG 37200-000, Brazil. *Corresponding author: djeison.raymundo@ dmv.ufla.br

${ }^{3}$ Faculdade de Veterinária, Universidade de Cuiabá (UNIC), Rua Itália s/n, Cuiabá, MT 78015-780, Brazil.

${ }^{4}$ Departamento de Patologia Clínica Veterinária, Faculdade de Veterinária, Universidade Federal do Rio Grande do Sul (UFRGS), Av. Bento Gonçalves 9090, Porto Alegre, RS 95320-000, Brazil.

${ }^{5}$ Departamento de Clínica Médica Veterinária, Faculdade de Agronomia e Medicina Veterinária, Universidade Federal de Mato Grosso (UFMT), Av. Fernando Corrêa s/n, Coxipó, Cuiabá, MT 78060-900.
}

urinária com metástase em vértebras lombares e compressão da medula espinhal em uma jaguatirica fêmea adulta (Leopardus pardalis), no estado do Mato Grosso. A jaguatirica manifestava paralisia de membros pélvicos e úlceras de decúbito na região posterior do corpo e foi submetida a eutanásia. Na necropsia observou-se um nódulo multilobulado e irregular, brancoamarelado na bexiga urinária, de consistência macia com origem na mucosa vesical e que se estendia às camadas musculares e à serosa. Nódulos de aspecto semelhante infiltrando as vértebras L6 e L7 e invasão do canal vertebral correspondente. No exame histológico foi observada proliferação neoplásica na bexiga urinária com com características de TCC não papilar e infiltrativo, com marcação imuno-histoquímica positiva para pancitoqueratina, forte marcação para citoqueratina de baixo peso molecular e fraca ou inexistente para citoqueratina de alto peso molecular. Este é o primeiro relato de TCC em bexiga urinária de jaguatirica no Brasil. 
TERMOS DE INDEXAÇÃO: Carcinoma de células de transição, bexiga urinária, jaguatirica, Leopardus pardalis, neoplasia epitelial, sistema urinário, imuno-histoquímica, citoqueratina, felino selvagem.

\section{INTRODUCTION}

The ocelot, Leopardus pardalis (Carnivora: Felidae) is a medium size feline, weighing 8 to $15 \mathrm{~kg}$, with a robust sturdy body and short legs. The coat usually has rounded spots of black color on a yellowish background (Leme et al. 2003). The ocelot has a wide geographical distribution and is found throughout the American forest, from the southern Texas (USA), throughout Mexico and Central America to northern Argentina, with the exception of Chile (Kaminski et al. 2013). The ocelot has a natural habitat in the forest, and areas of high grass (Leme et al. 2003). In Brazil occurs in all regions and biomes, except the southern state of Rio Grande do Sul. These felids are included in the official list of endangered animal species and have been allocated in captivity (IBAMA 2014).

The increasing number of senile wild felines in Zoos possibly has resulted in several diseases, including neoplastic processes (Miranda et al. 2003). A retrospective study (1971-2002) of necropsy cases of São Paulo Zoological Park Foundation showed neoplasia in 27 animals, $33 \%$ of those in wild felines (Miranda et al. 2003). In ocelot (Leopardus pardalis), were described cases of auricular squamous cell carcinoma (Leme et al. 2003) and uterine leiomyoma (Gonçalves \& Oliveira 2000). Neoplasms of the urinary tract are considered unusual in all domestic species. Among the several types of cancer, neoplasms of urinary bladder are the most frequently reported, especially in dogs, in which correspond to a 0,5 to $1 \%$ of urinary tumors (Tarvin et al. 1978, Serakides et al. 2000). In wild felines rare cases were described; all cases in small wild felines. Four cases of urinary bladder neoplasia was described the fishing cats (Prionailurus viverrinus) (Sutherland-Smith et al. 2004).

Generally the clinical signs displayed by affected animals are suggestive of lower urinary tract disease, and may includ hematuria, stranguria, pollakiuria, tenesmus, abdominal pain and urinary incontinence (Tarvin et al. 1978, Norris et al. 1992, Serakides et al. 2000, De Moura et al. 2007, Froes et al. 2007). Transicional cell carcinomas are generally originated in the trigone region of the urinary bladder and may invade adjacent structures such as ureters and urethra (Tarvin et al. 1978, Norris et al. 1992, Serakides et al. 2000). The most common sites of metastasis are the regional lymph nodes, lungs and liver (Nikula et al. 1989, Serakides et al. 2000). The diagnosis of urinary bladder tumor is performed by the association of clinical findings with imaging tests, urinalysis, and cytological or histopathological evaluations (Norris et al. 1992, De Moura et al. 2007). The long-term prognosis is poor, with median survival time of 4-6 months without treatment, possibly related to a progressive disorder (Henry 2003, De Moura et al. 2007).

In domestic cats, the most prevalent urinary tract tumors are lymphoma, especially those involving the kidney, nevertheless primary renal tumors are considered rare and aggressive neoplasms (Henry et al. 1999, Wilson et al. 2007). Primary epithelial tumors of the urinary tract include TCC and squamous cell carcinoma (Henry et al. 1999). Among urinary bladder tumors, $90 \%$ are epithelial and malignant, wherein the TCC is the most frequent, representing 50 to $75 \%$ of malignant urinary bladder tumors (Norris et al. 1992, Rocha et al. 2000, Henry 2003). Histologically, TCC are classified as papillary and infiltrating, nonpapillary and infiltrating, papillary and noninfiltrating, and nonpapillary and noninfiltrating (carcinoma in situ). The infiltrating varieties of TCC (papillary or nonpapillary) are more common than noninfiltrating. The nonpapillary and infiltrating variety is considered the most likely to metastasize (Meuten et al. 2004).

The diagnosis of tumors of the urinary bladder is commonly done by histopathological evaluation associated with immunohistochemical techniques, which allows to characterize and classify accurately tumoral histogenesis, particularly in cases of poorly differentiated neoplasms (Alexa et al. 2010). The cytokeratin and vimentin are the major cell markers used for the histogenic characterization (Zuccari et al. 2004). Different cytokeratins (including low and high molecular weight), and polyclonal cytokeratins, also called pancytokeratins (Wu et al. 2002, Ohsaki et al. 2011). The high molecular weight cytokeratins are used primarily in cases of keratinized tumors, and low weight citokeratin are typically expressed in non-keratinized epithelium (Ramos-Vara et al. 2003).

This article aims to describe the pathological and immunohistochemical aspects of a case of urinary bladder TCC with lumbar metastasis in an ocelot (Leopardus pardalis).

\section{MATERIALS AND METHODS}

An adult female ocelot (Leopardus pardalis), from a private hatchery in the Mato Grosso state, Brazil, was referred for clinical care at the Hospital Veterinário da Faculdade de Medicina Veterinária da Universidade de Cuiabá (UNIC - HOVET). Because of the clinical condition with paralysis associated with diagnosis of tumoral mass in the urinary bladder and absence of response to treatment, the animal was euthanized. After euthanasia, the animal was referred to the Laboratório de Patologia Veterinária da Universidade de Cuiabá (UNIC) for necropsy. Fragments of brain, spinal cord, vertebral bone of L6 and L7, skeletal muscles, heart, lung, liver, spleen, lymph nodes, stomach, small and large intestine, adrenal, thyroid, skin, kidneys, urinary bladder, ureters, uterus and ovary were collected, fixed in $10 \%$ buffered formalin, embedded in paraffin, cut at $5 \mu \mathrm{m}$ sections and stained with hematoxylin and eosin. Sections of the urinary bladder, the lumbar vertebrae and spinal cord were submitted to immunohistochemical analysis for pancytokeratin, cytokeratin of high molecular weight, cytokeratin of low molecular weight and vimentin. The antibody clones, dilution of primary antibodies, antigens retrieval and source were presented at Table 1 . Sections were incubated with biotinylated secondary antibody followed by streptavidin-peroxidase (LSAB-HRP kit K0690, DakoCytomation), as chromogen used the 3,3'diaminobenzidine (DAB-K3468, DakoCytomation) for developing and counterstaining with Harris hematoxylin. As positives controls were used a skin sample (pancytokeratin and cytokeratin of high molecular weight) normal urinary bladder without alteration (cytokeratin of low molecular weight) and a fi- 
broma uterus (vimentin). As a negative control were replaced the primary antibodies by PBS (phosphate buffer saline).

Table 1. Antigenic retrieval, dilutions, and origin of the primary antibodies used in the immunostaining protocols applied to the tissue sections from the ocelot with urinary bladder neoplasm.

\begin{tabular}{|c|c|c|c|c|}
\hline Antigen & $\begin{array}{l}\text { Antibody } \\
\text { clone }\end{array}$ & $\begin{array}{l}\text { Antigen } \\
\text { retrieval }^{\mathrm{a}}\end{array}$ & $\begin{array}{l}\text { Antibody } \\
\text { dilution }\end{array}$ & Source \\
\hline Pancytokeratin & clone AE1/AE3 & $\begin{array}{c}\text { Citrate pH 6.0, } \\
125^{\circ} \mathrm{C}, 3 \mathrm{~min}\end{array}$ & $1: 80$ & Dako \\
\hline $\begin{array}{l}\text { Cytokeratin of high } \\
\text { molecular weight }\end{array}$ & Clone $34 \beta E 12$ & $\begin{array}{l}\text { Proteinase K } \\
\quad 3 \text { min }^{\mathrm{a}}\end{array}$ & $1: 75$ & Dako \\
\hline $\begin{array}{l}\text { Cytokeratin of low } \\
\text { molecular weight }\end{array}$ & $\begin{array}{c}\text { cytokeratin } 8 / 18, \\
\text { clone } 5 \mathrm{D} 3\end{array}$ & $\begin{array}{l}\text { Proteinase K } \\
3 \text { min }^{\mathrm{a}}\end{array}$ & $1: 40$ & Novacastra \\
\hline Vimentin & clone V9, 18-0052 & $\begin{array}{c}\text { Citrate pH 6.0, } \\
125^{\circ} \mathrm{C}, 3 \mathrm{~min}\end{array}$ & $1: 200$ & Zymed \\
\hline
\end{tabular}

${ }^{a}$ Room temperature.

\section{RESULTS}

The feline was presented with a clinical history of walk impairment who progressed to hindlimb paralysis and decubitus ulcers in the posterior region. Ultrasonography showed a mass at the urinary bladder mucosa. At the necropsy severe skin ulcers were observed as well areas of subcutaneous edema in hindlimbs and the pelvic. The urinary bladder had a multilobulated and irregularly shaped nodule, measuring about $5 \mathrm{~cm}$ of diameter. The nodule was yellowish to white, has a soft consistency and arised from the mucosa extending throughout the muscular layers and the serosa of the urinary bladder (Fig.1A). Nodules of similar appearance were observed around the ureters and infiltrating the psoas muscles and the lumbar vertebrae L6 and L7 invading the spinal canal (Fig.1B). Other macroscopic changes found consisted of yellowish liver with petechiae, lung with multiple reddish foci, small intestine with red and rough serous and hemorrhagic mucosa; and kidneys with mild dilatation of the pelvis.

On microscopic examination of the urinary bladder were observed areas of infiltrative proliferation of neoplas- tic epithelial cells on the mucosa. These cells are primarily round shaped, however highly pleomorphic cells and large amounts of bizarre mitotic figures were also seen (Fig.2A). In the cortical bone of lumbar vertebrae, were observed neoplastic epithelial cells forming acini; with replacement of bone matrix by connective fibrous tissue; thin trabecular bone with osteoclast proliferation (Fig.2B). There was infiltration of neoplastic epithelial cells in the external portion of the meninges at the lumbar spinal cord similar. These cells also resembled the neoplastic cells of the urinary bladder. In the spinal cord were observed multifocal death neurons and axonal degeneration (axonal spheroids).

There was positive immunohistochemical staining for pancytokeratin and low molecular weight cytokeratin (Fig.2C e 2D), weak immunoreactivity for high molecular weight cytokeratin (Fig.2E e 2F) and no immunoreactivity for vimentin in the samples of urinary bladder, lumbar vertebrae and spinal cord analyzed by evaluated by IHC technique.

\section{DISCUSSION}

The diagnosis of nonpapillary and infiltrating TCC of urinary bladder in this ocelot was based on gross and histological findings associated with the positive immunohistochemical reaction for pancytokeratin and low molecular weight cytokeratin. T-cell markers such as cytokeratin and vimentin has been employed as important tools to differentiate neoplasms of epithelial and mesenchymal origin (Zuccari et al. 2004). The use of polyclonal and monoclonal cytokeratin as cellular markers of urinary bladder TCC was also employed in the differential diagnosis of the numerous subtypes of carcinomas of epithelial origin of the urinary tract, mainly the differentiation between urinary bladder TCC and squamous cell carcinoma (Alexa et al. 2010).

In this study the immunophenotyping of primary tumors is usually performed by using a panel of polyclonal cytokeratins such as pancytokeratin, which allows marking of neoplasms of epithelial origin. Some monoclonal cytokeratin may also be useful in establishing a more specific

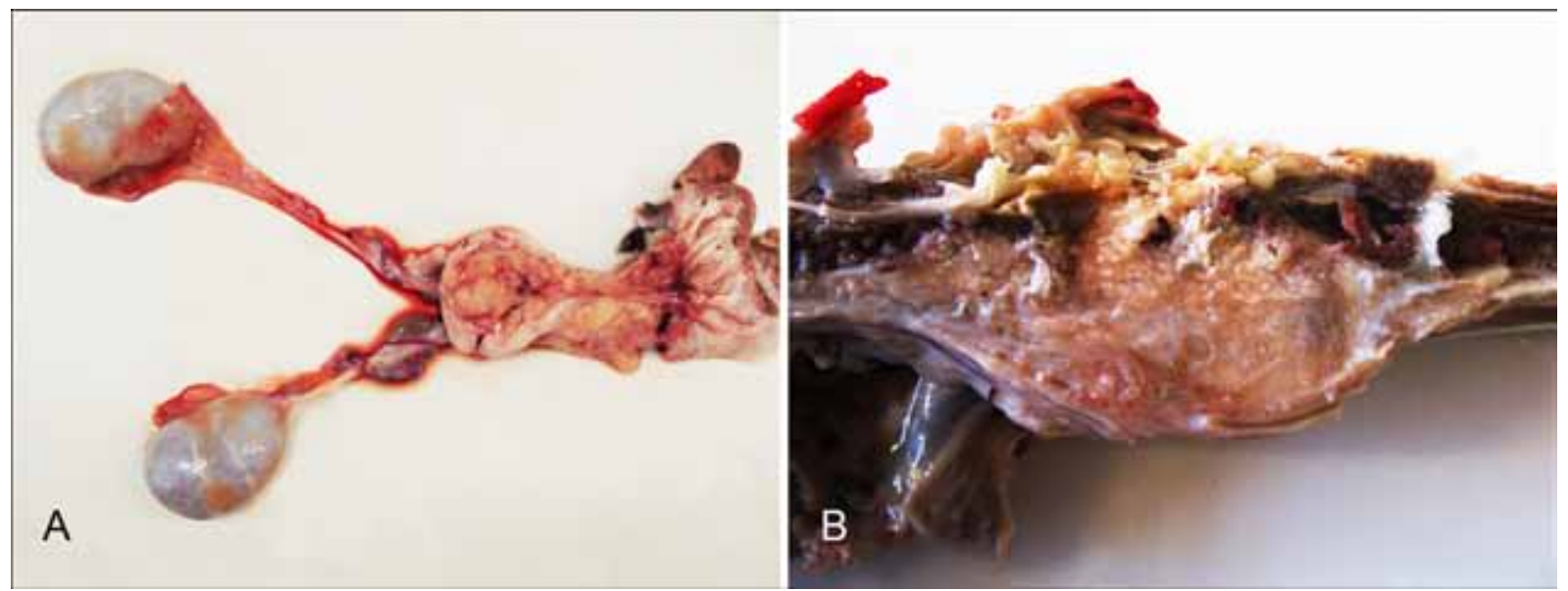

Fig.1. Ocelot (Leopardus pardalis). Transitional cell carcinoma. (A) Urinary bladder. Multilobulated and irregular shaped nodule yellowish to white arising from the mucosa and extending throughout the muscular layers and the serosa. (B) Lumbar vertebrae (L6-L7). Nodules of similar appearance to the urinary bladder neoplasm infiltrating the psoas muscle and the lumbar spinal canal. 

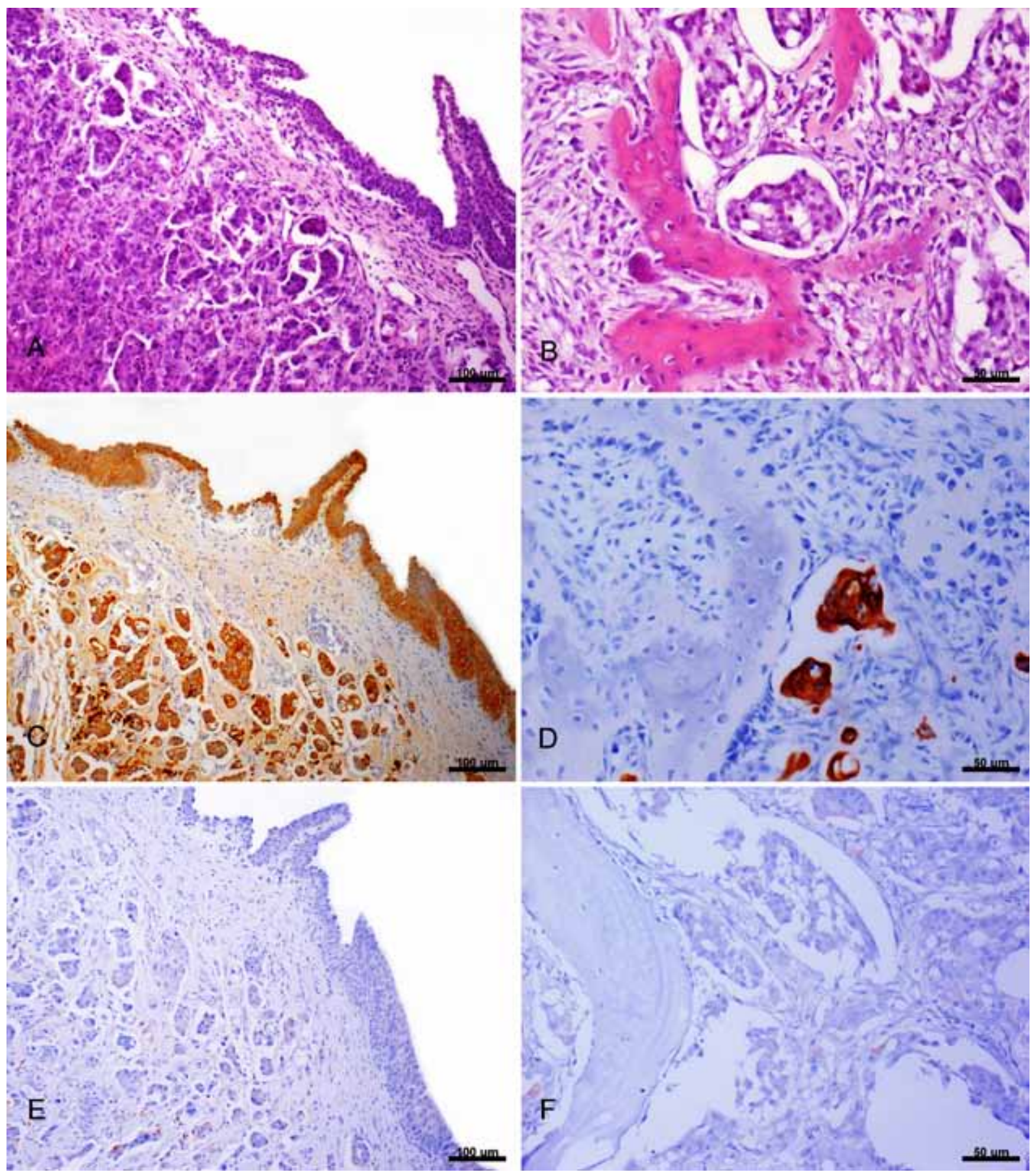

Fig.2. Ocelot (Leopardus pardalis). Transitional cell carcinoma. (A) Urinary bladder. Areas of infiltrative proliferation of neoplastic epithelial cells. Insert: Cells round shaped with highly pleomorphic cells and large amounts of bizzare mitotic figures. HE, obj.10x. (B) Lumbar vertebrae (L6-L7). Neoplastic urinary bladder epithelial cells forming acini with replacement of bone matrix by connective tissue and there were observed thin trabeculae bone with osteoblast proliferation. HE, obj.40x. (C) Urinary bladder. Positive immunohistochemical staining for cytokeratin of low molecular weight. Streptavidin-biotin peroxidase techique, DAB chromogen, obj.10x. (D) Lumbar vertebrae (L6-L7). Positive immunohistochemical staining for cytokeratin of low molecular weight. Streptavidin-biotin peroxidase technique, DAB chromogen, obj.40x. (E) Urinary bladder. Weak positive IHQ staining for cytokeratin of high molecular weight. Streptacidin-biotic peroxidase, DAB chromogen, obj.10x. (F) Lumbar vertebrae (L6-L7). Weak positive IHQ staining for cytokeratin high moleular weight. Streptocidin-biotic peroxidase, DAB chromogen, obj.40x.

diagnosis regarding the origin of the tumor cells (Wu et al. 2002, Alexa et al. 2010). Low molecular weight cytokeratins are commonly expressed in cancers originating from non-keratinized epithelium, such as the transitional epi- thelium of the urinary tract. However, in epithelia with high production of keratin an increased expression of high molecular weight cytokeratins occurs (Ramos-Vara et al. 2003). The expression of different cytokeratins can be used 
in differentiating squamous tumors, such as squamous cell carcinoma and carcinomas of the urinary tract, including the TCC (Ramos-Vara et al. 2003).

Immunohistochemical combined with histology helps to correct classification of subtypes of tumors of the urinary tract, especially in poorly differentiated tumors or tumors with an area of poor cellular differentiation. Immunohistochemical positive marked cells for pancytokeratin and cytokeratin of low molecular weight associated with a very weak immunoreactivity for cytokeratin of high molecular weight and negative for vimentin was observed in urinary bladder TCC of this case and are also described in carcinomas of the urinary tract (Wu et al. 2002, Alexa et al. 2010).

Primary tumors of the urinary tract, although rare, have been reported primarily in domestic animals (De Moura et al. 2007). In wild animals neoplastic processes are less often described, making difficult the establishment of a prognosis of these animals in captivity (Leme et al. 2003). In ocelot are described only cases of auricular squamous cell carcinoma (Leme et al. 2003) and intrauterine leiomyoma (Gonçalves \& Oliveira 2000). Infiltrative urinary bladder carcinomas have not been described in this species. TCC of urinary bladder generally originate in the trigone region, and invade adjacent structures such as ureters and urethra (Serakides et al. 2000).

The gross and histopathologic features of the TCCs in the oncelot described in this study are similar to reports in other species. Through these features allowing the classification of the tumor as nonpapillary and infiltrative, that is the variant most likely to metastasize (Meuten et al. 2004). Although infrequent, metastastatic infiltration of urinary bladder TCC to the lumbar vertebra results in spinal cord compression, leading to clinical signs such as hindlimb paralysis (De Moura et al. 2007), as observed in the oncelot of the present report. Hematuria is the most common clinical sign of bladder neoplasia in dogs and cats with TCC (Sutherland-Smith et al. 2004), however was not observed this or other urinary signal in the present study.

Based on pathologic findings associated with IHC results, it was possible to confirm the diagnosis of TCC of the urinary bladder in an ocelot (Leopardus pardalis). Although there were few reports of neoplasms in wild animals, there is a tendency for an increase in the incidence of diagnosed cases, possibly due to a long time survival of these animals in captivity. Thus, it is important to be alert to the occurrence of infiltrative or metastatic bladder tumors that lead to spinal cord compression and neurological signs in domestic and wild animals.

Acknowledgements.- We are very thankful to Dr. Flademir Wouters, of the Departamento de Medicina Veterinária, Universidade Federal de Lavras, for helpful with de pictures used in this study. The autors would like to thank CAPES (Coordenação de Aperfeiçoamento de Pessoal de Nível Superior), for Master's grant and FAPEMIG (Fundação de Amparo à Pesquisa do Estado de Minas Gerais), for the financial support.

\section{REFERENCES}

Alexa A., Baderca F., Lighezan R., Izvernariu D. \& Raica M. 2010. The diagnostic value of cytokeratins expression in the renal parenchyma tumors. Rom. J. Morphol. Embryo. 51:27-35.
De Moura V.M.B.D., Ferreira F.P.P., Rodrigues M.M.P., Caldeira C.P. \& Bandarra E.P. 2007. Carcinoma de células transicionais vesical em uma cadela São Bernardo: relato de caso. Vet. Notícias 13:75-79.

Froes T.R., Iwasaki M., Campos A.G., Torres L.N. \& Dagli M.L.Z. 2007. Avaliação ultra-sonográfica e pelo Doppler colorido do carcinoma de células transicionais da bexiga em cães. Arq. Bras. Med. Vet. Zootec. 59:1400-1407.

Gonçalves G.F. \& Oliveira S.T. 2000. Leiomioma uterino em jaguatirica (Leopardus pardalis): relato de caso. Arq. Ciênc. Vet. Zool. Unipar 3:185-188.

Henry C.J., Turnquist S.E., Smith A., Graham J.C., Thamm D.H., O'brien M. \& Clifford C. A. 1999. Primary renal tumours in cats: 19 cases (19921998). J. Feline Med. Surg. 1:165-170.

Henry C.J. 2003. Management of transitional cell carcinoma. Vet. Clin. North Am., Small. Anim. Pract. 33:597-613.

IBAMA (Instituto Brasileiro do Meio Ambiente e dos Recursos Naturais Renováveis) (2014). Lista Nacional das Espécies da Fauna Brasileira ameaçada de Extinção. <http://www.mma.gov.br/port/rbf/fauna/index.cfm> Accessed 4 Nov. 2014).

Kaminski N., Brandt A.P., Sampaio D.S., Fay K., Pereira L.C.M. \& Nicola P.A. 2013. New Record of Leopardus pardalis (Linnaeus, 1758) (Carnivora: Felidae) in the Caatinga of the state of Pernambuco, northeastern Brazil. Check List 9:860-861.

Leme M.C.M., Martins A.M.C.R.P.F., Bodini M.E.S., Carvalho P.R. \& Portugal M.A.S.C. 2003. Carcinoma de células escamosas em uma jaguatirica (Leopardus pardalis). Arqs Inst. Biológico, São Paulo, 70:217-219.

Meuten D.J., Everitt J. \& Inskeep W. 2004. Histological Classification of Tumors of the Urinary System of Domestic Animals. Armed Forces Institute of Pathology, Washington, DC, p.28-30.

Miranda F.R., Corrêa S.H.R., Teixeira R.H.F., Fedullo J.D.L. \& Catão-Dias J.L. 2003. Incidência de neoplasia em mamíferos na Fundação Parque Zoológico de São Paulo: estudo retrospectivo (1971-2002). Anais VII Congresso e XII Encontro da ABRAVAS, São Pedro, SP, p.83.

Nikula K.J., Benjamin S.A., Angleton G.M. \& Lee A.C. 1989. Transitional cell carcinomas of the urinary tract in a colony of beagle dogs. Vet. Pathol. 26:455-461.

Norris A.M., Laing E.J., Valli V.E.O., Withrow S.J., Macy D.W., Ogilvie G.K., McCaw D., Pidgeon G. \& Jacobs R.M. 1992. Canine bladder and urethral tumors: a retrospective study of 115 cases (1980-1985). J. Vet. Intern. Med. 6:145-153.

Ohsaki H., Hirakawa E., Nakamura M., Tsu Y.N., Kiyomoto H. \& Haba R. 2011. Expression of vimentin and high-molecular-weight cytokeratin (clone 34ßE12) in differentiating reactive renal tubular cells from low-grade urothelial carcinoma cells in voided urine. Cytopathology 22:247-252.

Ramos-Vara J.A., Miller M.A., Boucher M., Roudabush A. \& Johnson G.C. 2003. Immunohistochemical detection of uroplakin III, cytokeratin 7 , and cytokeratin 20 in canine urothelial tumors. Vet. Pathol. 40:55-62.

Rocha T.A., Mauldin G.N., Patnaik A.K. \& Bergman P.J. 2000. Prognostic factors in dogs with urinary bladder carcinoma. J. Vet. Intern. Med. 14:486-490.

Serakides R., Rachid M.A., Veado J.C. \& Menezes J.M.C. 2000. Carcinoma de células de transição da uretra com metástases cardíaca e pulmonar em cão. Arq. Bras. Med. Vet. Zootec. 52:430-432.

Sutherland-Smith M., Harvey C., Campbell M., McAloose D., Rideout B. \& Morris P. 2004. Transitional cell carcinomas in four fishing cats (Prionailurus viverrinus). J. Zoo Wildl. Med. 35(3):370-380.

Tarvin G., Patnaik A. \& Greene R. 1978. Primary urethral tumors in dogs. J. Am. Vet. Med. Assoc. 172:931-933.

Wilson H.M., Chun R., Larson V.S., Kurzman I.D. \& Vail D.M. 2007. Clinical signs, treatments, and outcome in cats with transitional cell carcinoma of the urinary bladder: 20 cases (1990-2004). J. Am. Vet. Med. Assoc. 231:101-106.

Wu S.L., Kothari P., Wheeler T.M., Reese T. \& Connelly J.H. 2002. Cytokeratins 7 and 20 immunoreactivity in chromophobe renal cell carcinomas and oncocytomas, Modern Pathology 15:712-717.

Zuccari D.A.P.C., Pavam M.V., Cordeiro J.A. \& Santana A.E. 2004. A imuno-expressão das citoqueratinas como marcadores diagnósticos e prognósticos nas neoplasias mamárias caninas. Revta Port. Ciênc. Vet. 99:173-178. 